\title{
Evaluating performance and development priorities of port industry in Ukraine
}

\author{
Natalia Mihai ${ }^{1 *}$, Larysa Hryshyna $^{1}$, Irina Khmarska $^{1}$, Elena Pogoryelova ${ }^{1}$, and Nataliia \\ Hryshyna $^{1}$ \\ ${ }^{1}$ Admiral Makarov National University of Shipbuilding, Prospekt Heroyiv Ukrayiny, 9, 54025, \\ Mykolayiv, Ukraine
}

\begin{abstract}
In this publication authors have evaluated seaports performance in Ukraine as part of transport infrastructure. It is highlighted that in modern conditions development of seaports as multifunctional entities capable of performing intermodal transportation, has a strategic impact on the country and might increase its competitiveness at international level. Peculiarities of port industry development in modern economic conditions and main problematic issues are defined, among which: low congestion of port facilities; irregular mechanism of public-private partnership; loss of transit flows by seaports; low level of digitalization in the area of transport and logistics activities; insufficient level of technical, technological and environmental safety in seaports. Strategic priorities of port industry development are substantiated, considering foreign experience and modern requirements of the world community.
\end{abstract}

\section{Introduction}

Current stage of port industry operating in Ukraine, being a part of transport infrastructure, is characterized by insufficient development, reduced competitive position and profitability due to significant depreciation of fixed assets, as well as underdeveloped port infrastructure. Effective seaports performance depends on effective management system, implementing modern technologies and equipment capable of ensuring Ukraine's competitive advantages in the world market.

In the context of country's integration into the world community, port industry plays the key role, because seaports are the link that might accelerate economic development. Seaport - is a complex transport and logistics hub that performs various functions and provides intermodal transport. Growth of international traffic and number of participants in foreign economic activity requires special attention to performance and defining priority directions for the development of seaports in Ukraine.

\footnotetext{
* Corresponding author: nataliamihai@,ukr.net
} 
In recent years domestic and foreign scientists quite actively cover in their scientific papers theoretical and practical aspects of state and development of port industry in Ukraine. Among them are T.G. Logutova [1], Yu.O. Lavruschenko [2], M.V. Makarenko[3], M.M. Poltoratsky [1], A.Z. Shaikhatdinov [3], V.V.Shemayev [4]. At present, there is a large number of unsolved legal, administrative, economic problems related to forming efficient infrastructure and full performance of seaports facilities in Ukraine.

The main aim of this paper is evaluating current state and peculiarities of Ukrainian port industry performance in modern conditions and substantiation of strategic development priorities considering foreign experience.

\section{Evaluating seaports performance in Ukraine}

Performance of seaports in Ukraine is provided by State Enterprise "Administration of Seaports of Ukraine" established in 2013 to maintain and use port infrastructure entities of state ownership, fulfill other tasks directly assigned or given through branches, formed in each seaport [6].

State Enterprise "Administration of Seaports of Ukraine" is one of the largest stateowned enterprises established in the result of reforming port industry of Ukraine and is subordinated to the Ministry of Infrastructure of Ukraine. Enterprise structure consists of headquarters in Kyiv, main representative office in Odesa, branches "Delta-Pilot" and "Dredging fleet", and also thirteen branches in seaports of Ukraine.

Ukrainian port complex currently consists of thirteen seaports (Fig. 1), which have various specializations: cargo, passengers, finished products, food, raw materials of industrial enterprises, etc. The total cargo handling capacity of seaports is 240 million tons per year. The largest ports in Ukraine are Yuzhny, Odessa, Mykolaiv and Chornomorsk. Their main advantages are: deep-sea approaches, which allow operating large vessels; favourable territorial location. Recently concentration of cargo traffic falls upon these ports, due to annexation of Autonomous Republic of Crimea and closing of seaports located on the peninsula until restoration of Ukrainian constitutional order; significant share of private business, stevedoring companies that provide ship maintenance and loading and unloading services.

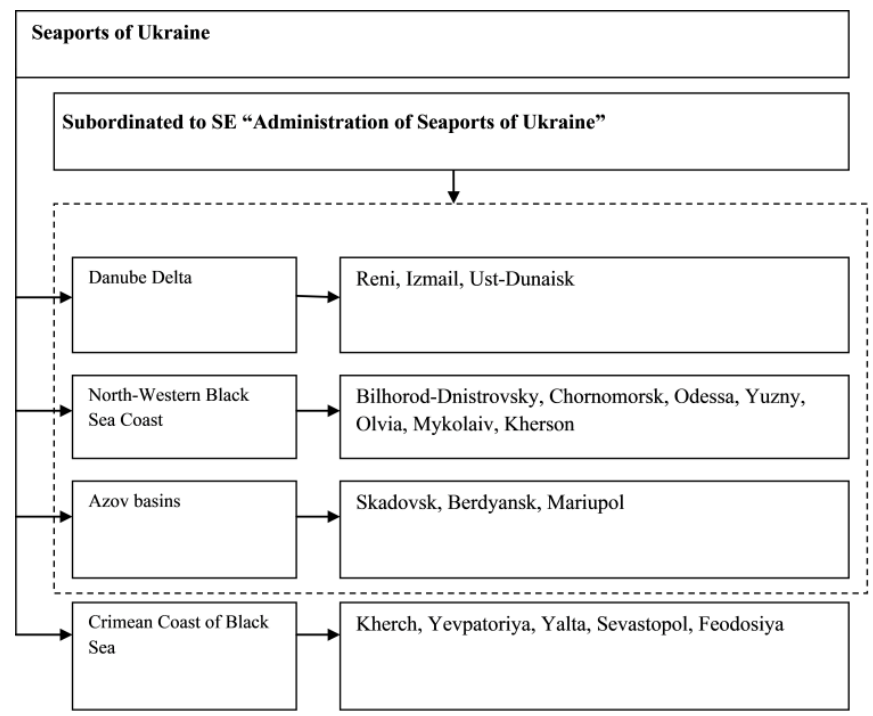

Fig. 1. National system of seaports of Ukraine. 
Other seaports of Ukraine accept vessels with less draft, cargo traffic is mainly serviced by state stevedoring companies. According to State Enterprise "Administration of Seaports of Ukraine" data, 1.01 million TEU containers were loaded by Ukrainian ports in 2019 [7]. This is much higher than the world average in the container market. Table 1 shows Ukrainian seaports congestion for the period of 2015-2019 years.

Table 1. Ukrainian seaports congestion during the period of 2015-2019 years [7].

\begin{tabular}{|c|c|c|c|c|c|c|c|}
\hline \multirow{2}{*}{ Port } & \multirow{2}{*}{$\begin{array}{c}\text { Port } \\
\text { capacity }\end{array}$} & \multicolumn{5}{|c|}{ Freight turnover, ml. tons } & \multirow{2}{*}{$\begin{array}{l}\text { Fluctuations } 2019 \\
\text { till } 2015, \%\end{array}$} \\
\hline & & 2015 & 2016 & 2017 & 2018 & 2019 & \\
\hline Odessa & 40 & 24.5 & 25.3 & 24.6 & 24.1 & 25.3 & +3.3 \\
\hline Chornomorsk & 32 & 14.5 & 15.9 & 17.6 & 17.2 & 26.2 & +80.7 \\
\hline Mariupol & 20 & 14.1 & 7.6 & 13.0 & 6.5 & 6.5 & -53.9 \\
\hline Mykolaiv & 21 & 10.8 & 22.4 & 20.8 & 23.5 & 33.4 & +209.3 \\
\hline Reni & 14,5 & 1.1 & 0.97 & 1.5 & 0.9 & 1.0 & -9.1 \\
\hline Berdyansk & 1 & 2.3 & 3.8 & 3.2 & 2.4 & 3.8 & +65.1 \\
\hline $\begin{array}{c}\text { Bilhorod- } \\
\text { Dnistrovsky }\end{array}$ & 1 & 0.9 & 0.5 & 0.6 & 0.4 & 0.5 & -44.4 \\
\hline Izmail & 8,5 & 2.9 & 5.6 & 3.1 & 5.7 & 5.7 & +96.6 \\
\hline Olvia & 3 & 2,2 & 6.4 & 6.8 & 6.9 & 6.5 & +195.5 \\
\hline Skadovsk & 1 & 0.2 & 0.03 & 0.06 & 0.03 & 0.03 & -85.0 \\
\hline Ust-Dunaisk & 4 & 0.03 & 0.03 & 0.06 & 0.05 & 0.02 & -33.3 \\
\hline Kherson & 5 & 3.1 & 3.7 & 3.9 & 3.3 & 3.7 & +19.4 \\
\hline Yuzhny & 40 & 22.7 & 39.3 & 47.4 & 41.9 & 53.9 & +137.4 \\
\hline
\end{tabular}

Results of carried out analysis in table 1 indicate that only eight of the thirteen ports have positive dynamics of freight turnover. Ports of Mykolayiv ( $+209.3 \%)$, Olvia (+ $195.5 \%)$, Yuzhny $(+137.4 \%)$, and Chernomorsk $(+80.7 \%)$ show the highest growth rates of cargo handling. Decrease in cargo handling in the ports of Mariupol $(-53.9 .0 \%)$, Skadovsk (-85.0\%), Reni (-9.1\%) might be explained, on the one hand, by close location to military-political conflict in the East Ukraine, and on the other hand - the fact that these ports have problems with insufficient capacity of port railway stations and unsatisfactory railway connections. These problems should be solved at the state level. In particular, in August 2020, port of Reni received tax exemption - zero rate of land tax, which will be valid for one year and is aimed at stabilizing stevedoring company situation, promoting private stevedoring business and increasing cargo handling [9]. We also see cargo handling decrease in port of Ust-Dunaisk (-33.3\%), which is explained by almost complete absence of vessel calls, imports and transit.

In this paper authors have carried out analysis of carriage of goods by sea according to cargo type (Table 2).

General tendencies of carrying goods by sea in 2015-2019 years are negative: in $2015-$ 3292 thousand tons of goods were carried, and in $2019-2120$ thousand tons, that is $35.6 \%$ less. A more detailed examination shows that during analyzed period carriage of goods increased in three positions: grain $(+433 \%)$, coke $(+200 \%)$, paper $(+133.3 \%)$. At the same time carriage of specific weight of each cargo type differs in different years. Thus, if in 2015-2016 iron ore had the largest specific weight of carriage $(27.1 \%-2015 ; 23.9 \%-$ $2016)$, various metals $(35.5 \% ; 35.5 \%)$, other cargoes $(25.3 \% ; 28.7 \%)$, then in $2017-2019-$ various metals $(47.2 \% ; 53.2 \%$; $48.6 \%)$ and grain $(25.0 \%$ in $2018 ; 27.7 \%$ in 2019$)$. 
Table 2. Dynamics of goods carried by sea during the period of 2015-2019 years, (thsd, tons) [7, 9].

\begin{tabular}{|c|c|c|c|c|c|c|c|c|c|c|c|}
\hline $\begin{array}{c}\text { Cargo } \\
\text { type }\end{array}$ & $\frac{n}{2}$ & 递总 & 을 & कृ & $\frac{}{2}$ & कृ & $\stackrel{\infty}{\stackrel{\sim}{*}}$ & 窇 & हे & 窇递 & 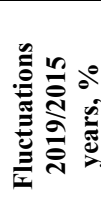 \\
\hline $\begin{array}{c}\text { Total } \\
\text { cargo } \\
\text { volume }\end{array}$ & 3292 & 100 & 3033 & 100 & 2253 & 100 & 1892 & 100 & 2120 & 100 & - \\
\hline \multicolumn{12}{|l|}{ Including } \\
\hline $\begin{array}{l}\text { Oil and oil } \\
\text { products }\end{array}$ & 71 & 2,2 & 53 & 1.74 & 32 & 1.42 & 30 & 1.6 & 30 & 1.4 & -57.7 \\
\hline Coal & 28 & 0.85 & - & - & - & - & - & - & 5 & 0.23 & -82.2 \\
\hline Coke & 6 & 0.18 & 27 & 0.89 & 34 & 1.5 & 23 & 1.2 & 18 & 0.85 & +200.0 \\
\hline Iron ore & 892 & 27.1 & 725 & 23.9 & 272 & 12.1 & 38 & 2.0 & 58 & 2.7 & -94.5 \\
\hline $\begin{array}{l}\text { Building } \\
\text { materials }\end{array}$ & 110 & 3.34 & 68 & 2.24 & 95 & 4.2 & 71 & 3.75 & 96 & 4.5 & -12.7 \\
\hline $\begin{array}{l}\text { Chemical } \\
\& \text { mineral } \\
\text { fertilizers }\end{array}$ & 32 & 0.97 & 17 & 0.56 & 10 & 0.44 & 12 & 0.63 & 9 & 0.42 & -71.9 \\
\hline Wood & 7 & 0.2 & 55 & 1.8 & 4 & 0.2 & 6 & 0.3 & 2 & 0.09 & -71.4 \\
\hline Paper & 3 & 0.09 & - & - & - & - & 3 & 0.15 & 7 & 0.33 & +133.3 \\
\hline $\begin{array}{l}\text { Various } \\
\text { metals }\end{array}$ & 1170 & 35.5 & 1077 & 35.5 & 1063 & 47.2 & 1006 & 53.2 & 1030 & 48.6 & -11.9 \\
\hline Grain & 110 & 3.34 & 100 & 3.3 & 204 & 9.05 & 473 & 25.0 & 587 & 27.7 & +433.6 \\
\hline $\begin{array}{l}\text { Container } \\
\text { cargo }\end{array}$ & 30 & 0.91 & 38 & 1.25 & 8 & 0.35 & 0 & - & - & - & -100.0 \\
\hline $\begin{array}{l}\text { Other } \\
\text { cargoes }\end{array}$ & 833 & 25.3 & 873 & 28.7 & 531 & 23.6 & 230 & 12.2 & 278 & 13.1 & -66.6 \\
\hline
\end{tabular}

Evaluating structure of exports and imports of main cargo groups in 2018-2020 years (Fig. 2) shows overall positive dynamics of cargo handling by stevedoring companies in seaports of Ukraine with significant predominance of exports. By specific weight, export dynamics is amounted to: $74.4 \%$ - in $2018 ; 76.6 \%$ - in $2019 ; 78.48 \%$ - in 2020 .

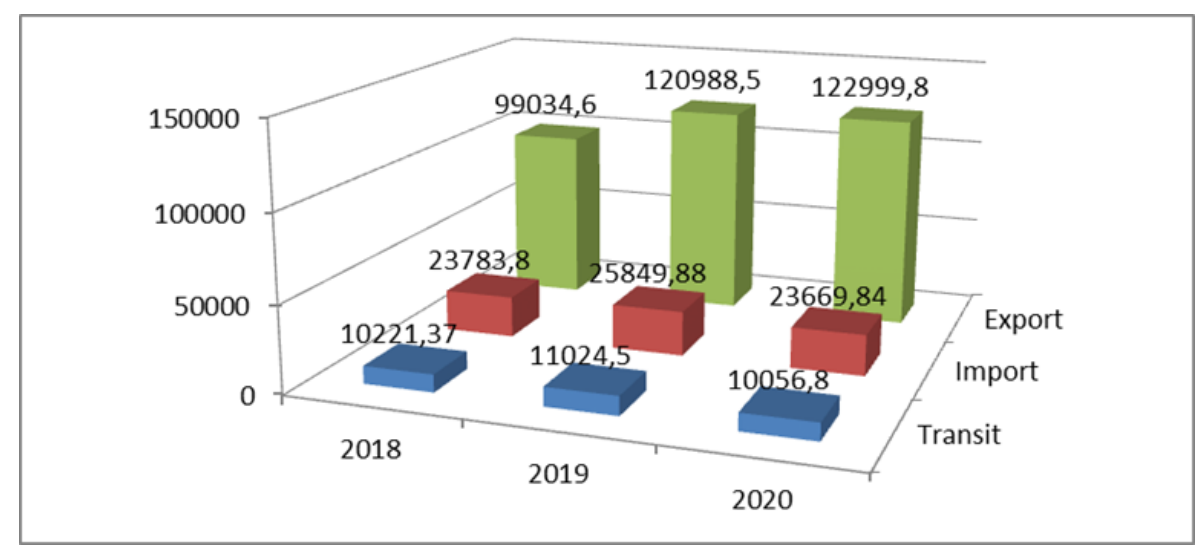

Fig.2. Dynamics of general cargo handling by stevedoring companies in seaports of Ukraine (thsd. tons). 
At the same time, we observe decrease in imports and transit. Thus, if we compare volumes of transit of goods through seaports of Ukraine in 2014 and 2020, transit has decreased more than twice $(-51.5 \%)$. Decrease in transit volumes may indicate irregular logistics systems and customer's distrust, cargo reorientation to other countries ports, including the Baltic States, Germany, Poland, Romania [10].

Seaports of Ukraine are called by the 15 largest shipping companies, which account for $99.5 \%$ of the total volume of containers. The top three are Maersk Line, CMA CGM, MSC, which provide more than half of entire container market in Ukraine $(53.5 \%)$.

Ports of Ukraine are included in routes of the following ocean services:

1) Bosphorus Express Service (BEX) -weekly service of Ocean Alliance with calls to seaport of Odessa

2) ZIM Med Pacific (ZMP) -weekly service of ZIM company from Far Eastern ports with a call to seaport of Odessa;

3) ECUMED -weekly service of Maersk Line from Latin America with a call to the seaport Yuzhny;

4) Middle East (ME3) -weekly service of Maersk Line, which connected Ukrainian ports with the Middle East countries [11].

Unfortunately, despite the fact that indicators of Ukrainian seaports performance are generally positive, the level of competitiveness of maritime infrastructure is still low. Thus, according to the World Economic Forum (WEF) estimation, indicator of "accessibility and quality of port infrastructure" in 2018 was 3.2 out of possible seven (the estimate varies from 1 (port infrastructure is not developed) to 7 (port infrastructure meets all international standards) [12].

To sum up, analysis of seaports performance in Ukraine enabled us to define a number of problems that hinder their development and require government and business to work closely together in solving them and forming strategic development priorities for the future. Among them, in author's view the most essential are:

- low congestion of port facilities mainly due to the lack of efficient port infrastructure (low capacity of automobile and railway connections);

- $\quad$ irregular mechanism of public-private partnership and attraction of investments in the development of the port area;

- $\quad$ loss of transit flows by seaports;

- $\quad$ low level of digitalization in the area of transport and logistics activities;

- $\quad$ insufficient customs clearance procedures, corruption;

- $\quad$ insufficient level of technical, technological and environmental safety in seaports.

\section{Priority directions of port industry development in Ukraine}

Legal framework for seaports activity in Ukraine is Law of Ukraine "On Seaports of Ukraine" [6], National Transport Strategy of Ukraine until 2030, Strategy for Development of Seaports of Ukraine for the period up to 2038 [8]. In addition, Law of Ukraine "On Multimodal Transportation" is going to be approved to introduce legal mechanisms for more efficient use of multimodal freight transportation in the transport system of Ukraine. This will help to improve environmental component of transport through wider use of environmentally friendly modes of delivery, as well as optimize time and costs through implementing single agreement for multimodal transportation.

Considering that port industry in Ukraine is undergoing reforming process and ensuring level of activity that meets European standards, taking into account experience of developed countries, it is necessary to focus on Memorandum of the European Sea Ports. Priorities of European ports 2019-2024 [12]. 
According to the memorandum, the TOP-10 priorities for port industry development have been identified. In particular, the first priority determines that port administrations are the main component of port system, as they establish, regulate, control relationship between all stakeholders on the basis of financial transparency, competition, adaptation of port ecosystem to changes in the environment.

The second priority assumes that port authorities continue to be hybrid, that means, on the one hand, gain more financial autonomy and, on the other hand, become more socially responsible.

The third priority is that investment in European ports is an investment in European competitiveness. The main principle of trade policy should remain openness in receiving investments.

The fourth priority determines that multimodal communication is basic link between ports and logistics centers within the countries. It is stated that according to recommendations of Trans-European Transport Network (TEN-T), main seaports should have been connected by rail, road, water (where possible) by 31 December 2030. Despite the fact that such connection already exists, there is necessity for constant improving multimodal connections, in fact to invest in upgrading outdated railway and port infrastructure for their better efficiency.

The fifth priority defines the role of digitalization in improving ports operating efficiency as an essential supply chain. It is emphasized that digitalization is one of the biggest coordinators of interrelations between transport and logistics industries. And port authorities should help accelerate digitalization processes in this area.

The sixth priority highlights necessity for carrying out decarbonization measures, in particular increasing role of renewable energy in ports, which should significantly reduce carbon emissions and use of non-renewable energy resources. Responsibility for this strategy efficiency lies on International Maritime Organization (IMO), which has promised to reduce greenhouse gas emissions from vessels by at least $50 \%$ by 2050 compared to 2008, and subsequently until their complete cessation. Besides, European governments should support investments aimed at implementing strategy of port decarbonization and increasing resilience to climate change.

The seventh priority is directly related to the previous one, as it indicates that air quality - is the basis of relationship between ports and cities. In recent years, air quality has been a major environmental priority for seaport administrations in their relations with cities, as polluted air and water create significant environmental risks to public health.

The eighth priority identifies European ports tasks, which are the largest participants in the open trade environment. About $75 \%$ of European foreign trade and more than a third of its domestic trade is handled with the help of port industry, so creating any barriers to ports will negatively affect economic security of business.

The ninth priority defines that ports performance must be licensed and cannot be carried out without local community permission. $91 \%$ of ports are located near cities and are mostly perceived by population as part of urban infrastructure. Accordingly, communities demand from ports their performance transparency, dialogue with port administrations concerning security and their impact on environment. Administrations, for their part, are demonstrating initiatives to reduce external effects and improve environmental situation through independent audits and production of annual environmental reports setting a number of environmental priorities.

The tenth priority emphasizes creating pan-European policy in transport sector and its coordination with other policies at EU level (environment, customs, competition, energy, maritime affairs, research) [13]. 
At present, according to updated by Ministry of Infrastructure of Ukraine "Strategy for seaports development in Ukraine until 2038" we will identify the following priority areas for development of domestic port industry:

1) development of mechanisms implementing "Port Landlord" management model, according to which the state, represented by seaport administration, has the right to give investors port infrastructure entities and land areas for construction under lease or concession agreements, and investors have the right to use built terminals for a certain period of time, after which they can either extend the contract or return land together with terminal.

Action in this direction has already been taken, so in June 2020 concession agreement was signed for port of Kherson transfer to management of Risoil-Kherson LLC, which invests UAH 300 million in port and its infrastructure development. In August 2020, Ukrainian port of Olvia (Mykolaiv) was transferred to Qatari company "QTerminals" for concession. The company has committed to invest UAH 3.4 billion over the next five years in port and its infrastructure development. Projects for concession of railway and ferry complex and first and container terminals of port of Chernomorsk are under discussion with Turkish companies "CLK" (Çalık Holding) and "Busserk".

2) optimizing non-profit seaport administrations performance by their intergration on regional basis. These processes are aimed at reducing number of Administrations of Seaports of Ukraine branches in accordance with geographical distribution of ports. For example, to combine administrations of ports of Mariupol, Berdyansk, Skadovsk in Mariupol; Mykolaiv, Kherson, Olvia - in Mykolaiv; Reni, Izmail, Ust-Dunaisk- in Reni. At the same time to leave branches of administration in ports of Odessa, Yuzhny, Chernomorsk because of high ports capacity. Such optimization will significantly reduce administrative staff costs and solve the problems of ports in these regions.

3) creating mechanism for local governments participation in the processes of planning seaports development with possibility of joining seaports councils. In the conditions of decentralization processes which have been carried out in Ukraine for three years and aimed at creating capable, independent territorial communities, seaports development as a part of territorial infrastructure is able to create conditions for socio-economic development, increase job places, investments etc.

4) introduction of corporate management standards in port industry; Recently, there have been tendency in the world of port administrations corporatization. More than $50 \%$ of port administrations of European Union are corporatized commercial structures and function as independent companies Ltd-"Limited Companies", SA-"Sociétée Anonyme", GmbH, AB-“Aktiebolag”, SpółkaAkcyjna, etc. [14]. Corporatization of Administration of Seaports of Ukraine will contribute to attraction of investment in port infrastructure development, simplified debt financing, reducing cost of servicing the berth line transferring this right to investors, transparency in decision-making, establishment of subsidiaries and acquisition of corporate rights.

5) development of electronic services in seaports. The main characteristic of world leading ports is digitization of all aspects of port performance, including operating, planning, design, development and maintenance of infrastructure.

Among the main innovative technologies used in leading seaports, the following should be singled out: using robotic and remotely controlled loading and unloading systems, which enable moving to container terminals automation; using Internet of Things, by implementing appropriate software for effective management of vessels traffic; implementing Blockchain technology to track cargo movement and inform stakeholders during the supply chain.

6) implementation of smart infrastructure, environmentally friendly technologies aimed at reducing harmful emissions from production processes in ports and obtaining energy 
from alternative sources; The main components of smart infrastructure existing in Ukraine today, which are already used or being just implemented are: E-services (use of information and communication technologies in various sectors of economy); E-ticket - system implementation for ticket sales for any type of transport with possibility of combining transport types; Enterprise Resource Planning (ERP) - corporate information system for automation of planning, accounting, control and analysis of all major business processes, supply logistics management, personnel management, etc.; open budget - creating conditions to satisfy citizens needs getting information about using state and local budgets by Ministry of Infrastructure of Ukraine and state enterprises which are subordinated to the Ministry; open data - automatic presentation of open data registers that are filled in and maintained by state enterprises; E-transport (aviation, rail, road, water) - creating single transport model, logistics schemes at different levels, real-time optimization of freight and passenger traffic, traffic flows;

7) implementing information system "Ukrainian National Maritime Single Window" with its further integration into information systems of controlling bodies. This is information system that will enable to collect and analyze data about vessels calling Ukrainian ports in an orderly manner, giving access to country's revenue and collection authorities. The single window will allow executive branch to better interact in terms of sanitary-epidemiological, veterinary-sanitary, phyto-sanitary, ecological, radiological and other types of state control.

The single sea window will be implemented by State Enterprise "Administration of Seaports of Ukraine", and information systems of electronic interaction with it will be implemented by port community members jointly or separately. The term "port community" means two or more entities operating in a seaport; public authorities responsible for various types of control; agents, freight forwarders and entities. Ukrainian National Maritime Single Window is created on the basis of technical solutions compatible with SafeSeaNet.

8) integration of Ukrainian segment "Ukrainian National Maritime Single Window" with European Ship Monitoring System SafeSeaNet (SSN), which is aimed at exchanging between Member States all relevant information about vessels movement and exact nature of cargo carried, as well as historical information about individual vessels movement during marine environment and efficiency of maritime transport and maritime transportation.

\section{Conclusions}

Port industry is an important part of transport system in Ukraine. Competition in international market, a large number of problems of Ukrainian seaports are facing today, require not only implementing a set of measures, but also using all efforts by the state, private business, local communities to solve them. Country has already had some developments, highlighted in the Strategy for development of seaports in Ukraine for the period up to 2038 and a number of other regulations in this area and Ukraine is carrying out stage implementation of defined priorities.

We consider that port industry reforming must be carried out considering international experience and current requirements of world community. This will attract investments into port infrastructure modernization, introduce effective electronic services, strengthen social and environmental responsibility of port administrations and ensure state competitiveness in the world market. 


\section{References}

1. Logutova, T., \& Poltoratskiy, M. (2017). Analysis of the activities of Ukrainian seaports: prospects for development. Reporter of the Priazovskyi State Technical University. Section: Economic sciences, (34), 68-75.

2. Lavrushchenko, Yu. (2020). Research of world trends development of seaports. Manager. Bulletin of Donetsk State University of Management, 2(87), C. 156-166.

3. Makarenko, M., \& Shayhatdinov, A. (2016) Research of directions of specialization of seaports of Ukraine. Reporter of the Priazovskyi State Technical University. Section: Economic sciences, 31 (1), 176-183.

4. Shemayev, V. (2019) Special aspects of Ukrainian sea ports authority's transition to a corporate form of governance. Development of management and entrepreneurship methods of transport, 2(67), 76-88.

5. Shemayev, V. (2017). Strategic priorities of the development of the sea ports of Ukraine. Reporter of the Kharkov National Automobile and Highway University. Problems and prospects of entrepreneurship development, 3(18.2), 9-18.

6. The Verkhovna Rada of Ukraine (2012), The Law of Ukraine "About seaports". https://zakon.rada.gov.ua/laws/show/4709-17

7. Official site of the Ukrainian Sea Ports Authority. http://www.uspa.gov.ua

8. Ministry of infrastructure of Ukraine: An updated Strategy for the development of seaports until 2038. https://www.kmu.gov.ua/news/shvaleno-onovlenu-strategiyurozvitku-morskih-portiv-do-2038-roku-mininfrastrukturi

9. Seaports of Ukraine and Odessa region: results of 2019. https://morhoz.odessa.gov.ua/morski-porty-ukrayiny-ta-odeskoyi-oblasti-pidsumky2019-roku/

10. Mihai, N., (2020) Problems and prospects of development of seaports logistic infrastructure in Ukraine. Three Seas economic journal. 1(1). 53-59. http://doi.org/10.30525/2661-5150/2020-1-9

11. Krukliy, V. In 2019 seaports of Ukraine handled over $1 \mathrm{mn}$ TEU containers. https://www.kmu.gov.ua/news/u-2019-morski-porti-ukrayini-perevalili-ponad-1-mlnteu-kontejneriv-vladislav-kriklij

12. World Economic Forum (2021). https://www.weforum.org/reports/the-globalcompetitiveness-report-2020

13. European Sea Ports Organization (2019). Priorities of European Ports for 2019-2024. Memorandum of the European Sea Ports Organization for the new Commission and European Parliament. https://www.espo.be

14. European Sea Ports Organization (2017). Trends in EU Port Governance 2016, ESPO, Brussels. https://www.espo.be/publications/trends-in-eu-ports-governance-2016 